\title{
Could Economic Crises Change Economic Policy Uncertainty Impact on Economic Growth and Innovation?
}

\author{
Eva Kotlánová
}

\begin{abstract}
Innovation is a central driver of economic growth and development. It is the key that enables firms to successfully compete in the global marketplace, and the process by which solutions are found to social and economic challenges. Every country (firm) should be interested in investment in innovation. Nevertheless this area was affected too by economic crises (recession) significantly. Another important factor which impact innovation progress is stably, continual economic policy without repeated and strong fluctuations. This policy leads to higher investment rate and economic growth. How changed crisis the perception of predictability of economic policy? The aim of this paper is to find out (on the example of five largest European economies), how changed the perception of economic policy before crises and over the period of crises and its impact on investment, innovation and economic growth.
\end{abstract}

Index Terms-Economic growth, economic policy uncertainty, innovation, panel analysis regression.

\section{INTRODUCTION}

If the economy does not counter consequences of any special problems, the government keeps to its program under which it acquired the confidence of parliament. The main goal of government is to make a continual growth politics through clearly defined steps as the public investments or tax system are. Then this stable environment forms good conditions for firms which could invest e. g. in innovation and their development. However in economic crisis period governments are obligated to take special measure to counter the crises consequences, eventually to prevent its deepening. Each European country coped with recession in Europe, which started in 2007 in the United States and which is already known as crisis, differently. Nevertheless member countries of European Union were forced to limit government spending and increase budget revenues resulting in investment reduction and tax rate hikes, thus failing to contribute to kick-starting the economy and having rather the opposite effect. It was declared that these instruments should be used just for necessary time. If these steps are made transparently, are clear for economic subjects and its force is time-limited, they could be accepted from economic subject. The problem is, when the government acts vaguely, when it is not enough strong in order to get its concepts through parliament, when it has to negotiate with opposition about

Manuscript received February 15, 2014; revised December 28, 2014 This paper was supported by the project OPVK Innovation of study programs at the Silesian University, School of Business Faculty in Karviná, Project registration number CZ.1.07/2.2.00/28.0017.

Eva Kotlánová is with the Department of Economics, School of Business Administration, Silesian University, 73340 Czech Republic (e-mail: kotlanova@opf.slu.cz). concepts approval, when the government does not have clear conception and it changes it very often. In these cases economic policy uncertainty grows and economic subjects postpone investment decisions. This fact should become evident in innovation area too. The aim of this paper is to find out (on the example of five largest European economies), how changed the perception of economic policy before crises and over the period of crises and its impact on investment, innovation and economic growth. There will be used a method of panel regression.

\section{LITERATURE REVIEW}

Relationship between policy uncertainty and technological innovation was the area of interest of Markus [1], when he comes to the conclusion, that without certainty about government policies, business decision makers are unable to assess risk and opportunity and make the trade-offs necessary for investment in new technologies. Manso [2] illustrated the relative importance of policy versus policy uncertainty in determining innovation.

The negative impact of policy uncertainty has been long discussed [3]-[6], but there has been no tool how to measure the quantity. This was only changed by Baker, Bloom and Davis [7], who has recently published a working paper describing the construction of an index measuring Economic Policy Uncertainty (EPU) in the United States and several other selected countries. The higher is the value of index, the higher is the economic policy uncertainty. Their work builds on two views of the impact of uncertainty on economic performance [7]. The first is the literature on the impact of general economic uncertainty on investment; postulated that uncertainty with regard to the economy leads firms to postpone investment decisions [4]. Another reason why uncertainty is seen as a negative phenomenon is that it pushes up the costs of finance [8], and it increases managerial risk aversion [9].

The other group of authors [3], [4], [6], [10], [11] works with policy uncertainty. They consider the detrimental effects of monetary, fiscal and regulatory policy uncertainty on an economy. As policy uncertainty we can classify political instability too [12]. These topics are closely related. Political instability means that the government changes very often so its policy is not continual and it is perceived as uncertain.

\section{INDICATORS IN SELECTED COUNTRIES}

The most important indicators for this analysis were selected to demonstrate their progress before and over the crisis period in 5 largest European economies (Germany, the 
United Kingdom, France, Italy and Spain).

The economic crisis began in 2007 in the United States and with subsequently spilled over the Europe with the lag. The breaking point is September 15, 2008 when Lehman Brothers declared bankruptcy.

\section{A. Real Economic Growth and Investments}

In Fig. 1 there is illustrated a progress of real GDP in 5 largest European economies. It is clear, that before September 2008, GDP per Capita in US Current PPPs increased and after Lehman failure it declined sharply in all economies.

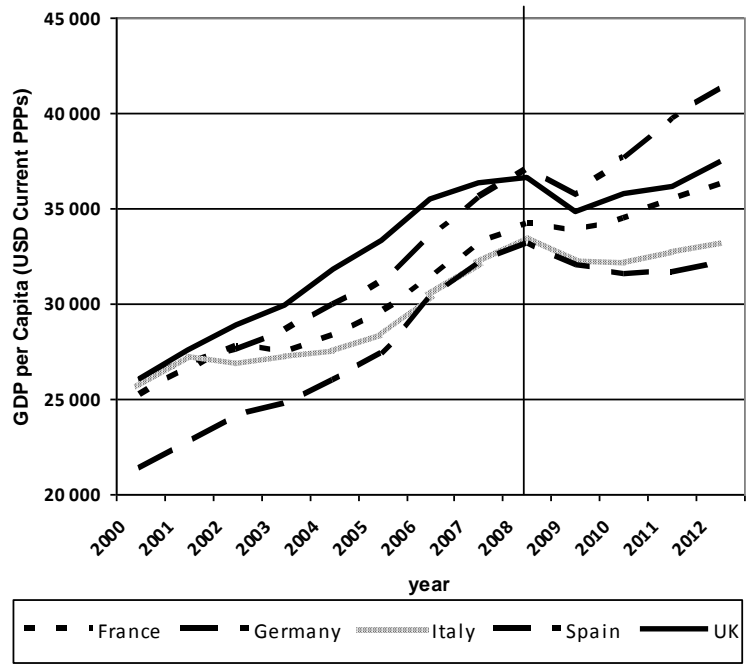

Fig. 1. GDP per capita in 5 largest European economies (2000-2012).

In Fig. 2 there is illustrated a progress of real investment rate relative to real GDP. As could be expected investments copy the GDP trend. This fact is not surprising. The original neoclassical Solow model and its further extension toward endogenisation of technological progress use real investment as one of the independent variables.

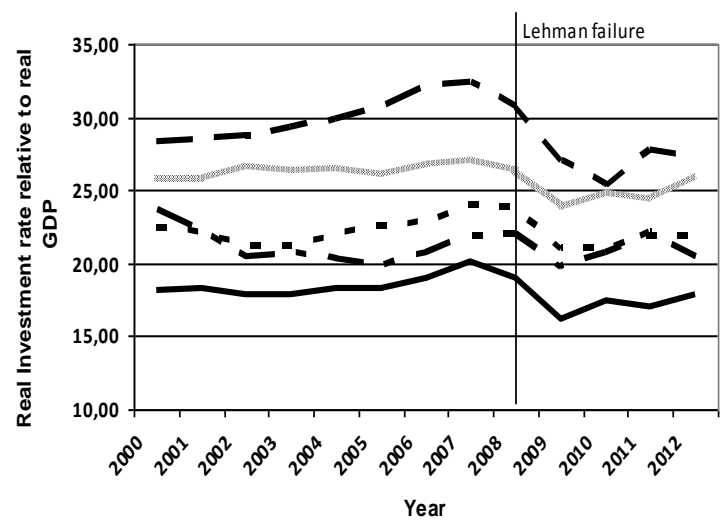

- - 'France - - Germany - Italy - -Spain —UK

Fig. 2. Real investment rate in 5 largest European economies (2000-2012).

\section{B. Economic Policy Uncertainty}

This index is produced by Scott Baker, Nicholas Bloom and Stephen Davis (henceforth BBD) for measuring economic policy uncertainty. Primarily it was constructed for US economy and consequently for some European countries.

Index for US is constructed from three types of underlying components [5]. First component quantifies newspaper coverage of policy-related economic uncertainty. Second one reflects the number and size of federal tax code provisions set to expire in future years and the third component uses disagreement among economic forecasters about policy relevant variables as proxy for uncertainty.

In Europe authors selected 5 largest European economies (Germany, the United Kingdom, France, Italy and Spain). Given that the legislation in the area of taxation in the European Union is not uniform, and that it is very extensive in each of the countries, it was not possible to use the second component in the construction of the index for European countries, or Europe as a whole. Thus, the authors based their overall policy uncertainty indices on $50 \%$ newspapers searches and $50 \%$ forecaster disagreement. To construct the first component, two newspapers from each of the countries were used, which include El Pais, El Mundo, Corriere della Sera, La Repubblica, Le Monde, Le Figaro, the Financial Times, The Times of London, Handelsblatt and FAZ.

As well as for the US version of the index, the authors analysed a number of newspaper articles containing specific selected terms (uncertain or uncertainty, economic or economy) as well as policy-relevant terms, which include: policy, tax, spending, regulation, central bank, budget and deficit. All searches are done in the native language of the newspaper in question. Each paper-specific series is normalized to standard deviation 1 prior to 2011 and then summed. The series is normalized to mean 100 prior to 2011 . The higher is the index value, the greater the uncertainty of economic policy.

To measure the second part of the index (forecaster disagreement), the Consensus Economics forecast database of public expenditure for each European country was used. For each country, BBD use data on individual forecast for the following calendar year of Consumption Price Index (CPI) and federal budget balances. The problem of seasonality is corrected with using interquartile ranges. So for the CPI disagreement measure BBD use the raw values. For the budget balance, they scale by a country's GDP. Index of each country is then scaled to standard deviation and summed to create a single European-wide index.

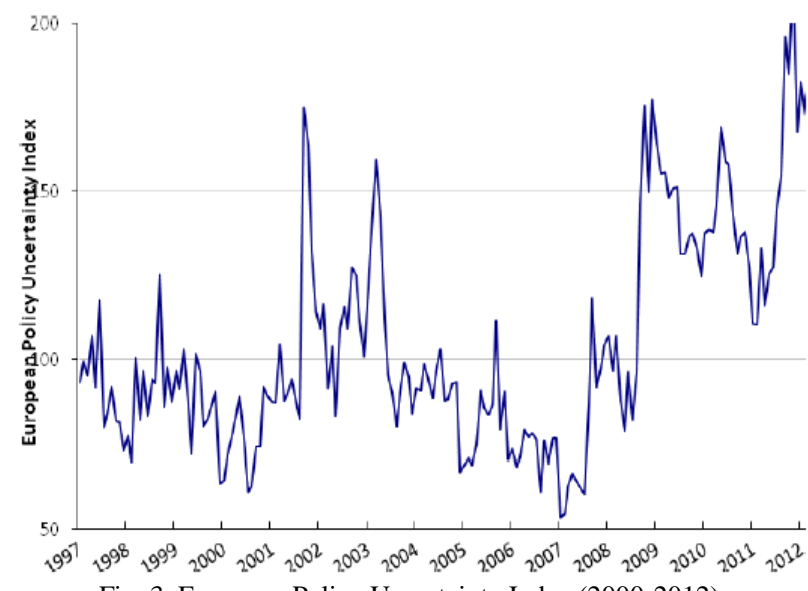

Fig. 3. European Policy Uncertainty Index (2000-2012).

Fig. 3, which shows the development of European Policy Uncertainty Index, clearly shows where the index reaches extreme values. These fluctuations can be assigned specific events. The first significant increase was reached in 
mid-1997, with the Asian crisis culminating at this time, followed by the Russian crisis in the second half of 1998. In 2001 , the index rose sharply to a value of 170 due to the September attacks on the World Trade Center in New York. In 2003, war in the Gulf broke out (Treaty of Accession and Gulf War II). In 2010, the Greek economy gets into trouble (Greek Bailout Request, Rating Cuts). The index reaches its highest values in 2011, involving a downgrade of Italy and after the Greek Prime Minister Papandreou stepped down after an unsuccessful referendum on Greek Eurozone exit.

\section{Innovation Index}

There are created many indexes which try to measure innovation potential, so one of the best known was chosen. It is Global Innovation Index (GII) [13]. The Global Innovation Index relies on two sub-indices, the Innovation Input Sub-Index and the Innovation Output Sub-Index, each built around pillars. Each pillar is divided into three sub-pillars and these are composed of individual indicators (total of 84 indicators).

The Innovation Input Sub-Index has 5 enables pillars:

- Institutions,

- Human Capital and Research,

- Infrastructure,

- Market Sophistication,

- Business Sophistication,

Which define aspects of the environment conducive to innovation within an economy. Institutions providing good governance and the correct levels of protection and incentives are essential to innovation. The level and standard of education and research activity in a country are the prime determinants of the innovation capacity of a nation. That is why Human Capital and Research are so important. Higher education is crucial for economies to move up the value chain beyond simple production processes and products. A good and ecologically friendly communication, transport, and energy infrastructure facilitates the production and exchange of ideas, services, and goods and feeds into the innovation system through increased productivity and efficiency, lower transaction costs, better access to markets, and sustainable growth (Infrastructure). The availability of credit, investment funds, and access to international markets are crucial for businesses to prosper, so Market Sophistication includes indicators like Credit, Investment or Trade competitions. The last pillar (Business Sophistication) tries to capture the level of business sophistication to assess how conducive firms are to innovation activity.

Innovation outputs are the results of innovative activities within the economy. Although the Output Sub-Index includes only two pillars, it has the same weight in calculating the overall GII scores as the Input Sub-Index. There are two output pillars:

- Knowledge and technology outputs

- Creative outputs.

Knowledge and technology outputs pillar covers all those variables that are traditionally thought to be the fruits of inventions and innovations. The role of creativity for innovation is still largely underappreciated in innovation measurement.

In Table I, there is shown the GII progress in time.
TABLE I: GLOBAL INNOVATION INDEX

\begin{tabular}{lcccccc}
\hline \hline & 2007 & 2008 & 2009 & 2010 & 2011 & $\begin{array}{c}201 \\
2\end{array}$ \\
\hline France & 4,32 & 4,35 & 4,20 & 4,71 & 4,92 & 5,18 \\
Germany & 4,89 & 4,99 & 4,32 & 4,85 & 5,49 & 5,62 \\
Italy & 3,48 & 3,65 & 3,47 & 3,68 & 4,07 & 4,45 \\
Spain & 3,38 & 3,81 & 3,74 & 3,98 & 4,38 & 4,72 \\
UK & 4,81 & 4,82 & 4,42 & 4,97 & 5,56 & 6,12 \\
\hline \hline
\end{tabular}

In all countries values of GII fell down in 2009 which is a consequence of the economic crisis and economic policy uncertainty. When the governments took measures to solve the crisis, the innovation index increased again.

Other indexes, which are used for measuring level of the innovation, are Knowledge Index (KI) and Knowledge Economic Index. These indexes are built by World Bank by using knowledge assessment methodology [14].

Knowledge Index (KI) measures a country's ability to generate, adopt and diffuse knowledge. This is an indication of overall potential of knowledge development in a given country. Methodologically, the KI is the simple average of the normalized performance scores of a country or region on the key variables in three Knowledge Economy pillars-education and human resources, the innovation system and information and communication technology.

The Knowledge Economy Index (KEI) takes into account whether the environment is conducive for knowledge to be used effectively for economic development. It is an aggregate index that represents the overall level of development of a country or region towards the Knowledge Economy. The KEI is calculated based on the average of the normalized performance scores of a country or region on all 4 pillars related to the knowledge economy-economic incentive and institutional regime, education and human resources, the innovation system and information and communication technology.

\section{DAta AND METhodology}

In this part panel regression will be used to prove or disprove the hypothesis about impact of EPU on economic growth.

In the regression analysis performed, the neoclassical model was used in its basic form, as recommended [15]. The theory of long-term economic growth is mainly based on the original neoclassical Solow model [16] and its further extension toward endogenisation of technological progress [17], [18].

The dependent variable was real GDP per capita in USD adjusted by purchasing power parity (PPP) and the independent variables were standard growth variables, understood as a control variable - the level of real investment relative to real GDP (INVESTMENT) and the variable describing the degree of uncertainty in economic policy (UNCERTAINTY).

The GDP per capita and the share of investment in GDP were obtained from the OECD iLibrary Statistics. The data approximating the level of uncertainty in economic policy was obtained from www.policyuncertainty.com, and are freely available, including the methodology of calculation. 
The periods under analysis were two: First before economic crisis in Europe 2001-2007 and second 2008-2012, which could ensure almost complete and reliable time series of economic crisis in France, Germany, Italy, UK and Spain.

The method used was the panel regression. Given the relatively small number of countries and the relatively short time series, the combination of time and cross-country data is absolutely essential. This makes the presented statistics more reliable. The software used was E-Views, version (7).

The regressions aimed to verify the hypothesis arguing the negative impact of economic policy uncertainty on economic growth.

In the first phase, the stationarity tests were performed using the "panel unit root test" according to Levin, Lin, Chu [19]. Only the UNCERTAINTY variable was found to be non-stationary. Its stochastic instability was removed in subsequent analyses using first differences. In terms of interpretation, it was also necessary to use the first differences for other variables. The problem of autocorrelation and heteroscedasticity was resolved by using a robust estimator which, when calculating the covariance matrices, ensures the correctness of the results of standard deviations of parameters and hypothesis tests with regard to a possible occurrence of autocorrelation and heteroscedasticity (White period).

The estimates employed the model with fixed effects, which is, according to Wooldridge [20], more suitable in the case of macroeconomic data. This procedure also relied on support of Hausman test.

TABLE II: REGRESSION FULL RESULTS

Dependent Variable: D(GDP)

Method: Panel Least Squares

Sample: $2001-207$

Periods Included: 7

Cross-section Included: 5

Total Panel (balanced) observation: 34

White Period Standard Errors \& Covariance (d.f. corrected)

\begin{tabular}{lcccc}
\hline Variable & Coefficient & Std. Error & t-Statistic & Prob. \\
\hline C & -0.143351 & 0.003595 & -39.87567 & 0.0000 \\
D (EPU) & -0.009864 & 0.003086 & -3.196326 & 0.0035 \\
D (INV) & 0.191087 & 0.071458 & 2.674125 & 0.0126 \\
\hline \multicolumn{5}{c}{ Effects Specification } \\
\hline
\end{tabular}

Cross-section fixed (dummy variables)

\begin{tabular}{lcll}
\hline R-squared & 0.352205 & Mean dependent var & -0.135655 \\
Adj. R -squared & 0.244917 & S.D. dependent var & 1.128307 \\
S.E. of regression & 0.980448 & Akaike info criterion & 2.979626 \\
Sum squared res. & 25.95449 & Schwarz criterion & 3.293877 \\
Log likelihood & -43.653654 & Hannan-Quinn criter. & 3.086794 \\
F-statistic & 2.783971 & Durbin-Watson stat & 2.849129 \\
Prob (F-statistic) & 0.030708 & & \\
\hline \hline
\end{tabular}

\section{EMPIRICAL ANALYSIS}

Full results of the regression for the reference period 2001-2007 are shown in Table II.

The analyses suggest that with a relatively high coefficient of determination (25\%) and at $5 \%$ level of model significance, a statistically significant ( $1 \%$ significance level) negative impact of economic policy uncertainty on economic growth was demonstrated in 2001-2007 in the developed EU economies. The effect of the control growth variable expressing the share of investment relative to GDP was, in line with common papers, described as positive (at $1 \%$ significance level).

The second period was 2008-2012, when the European countries countered the consequences of the recession. Full results of the regression are shown in Table III.

TABLE III: REGRESSION FULL RESULTS

Dependent Variable: D(GDP)

Method: Panel Least Squares

Sample: 2008 - 2012

Periods Included: 5

Cross-section Included: 5

Total Panel (balanced) observation: 25

White Period Standard Errors \& Covariance (d.f. corrected)

\begin{tabular}{lcccc}
\hline Variable & Coefficient & Std. Error & t-Statistic & Prob. \\
\hline C & 0.342662 & 0.274468 & 1.248460 & 0.2279 \\
D (EPU & -0.030066 & 0.014764 & -2.036421 & 0.0567 \\
D(INV) & 0.311142 & 0.065058 & 4.782542 & 0.0001 \\
\hline \multicolumn{5}{c}{ Effects Specification } \\
\hline
\end{tabular}

Cross-section fixed (dummy variables)

\begin{tabular}{lcll}
\hline R-squared & 0.743738 & Mean dependent var & -0.305557 \\
Adj. R -squared & 0.658317 & S.D. dependent var & 3.952442 \\
S.E. of regression & 2.310347 & Akaike info criterion & 4.744168 \\
Sum squared res. & 96.07864 & Schwarz criterion & 5.085454 \\
Log likelihood & -52.30210 & Hannan-Quinn criter. & 4.838826 \\
F-statistic & 8.706758 & Durbin-Watson stat & 2.576876 \\
Prob (F-statistic) & 0.000155 & & \\
\hline \hline
\end{tabular}

The analyses suggest that with a high coefficient of determination $(66 \%)$ and at $1 \%$ level of model significance, a statistically significant ( $1 \%$ significance level) negative impact of economic policy uncertainty on economic growth was demonstrated in 2008-2012 in the developed EU economies. The effect of the control growth variable expressing the share of investment relative to GDP was, in line with common papers, described as positive (at $1 \%$ significance level) and the effect of investment was quantitative higher than before economic crises.

\section{CONCLUSION}

Despite the impact of Economic Policy Uncertainty (EPU) being previously mentioned by some authors, a larger debate on this topic started only during the economic recession in the United States (2007-2009) which subsequently spilled over the Europe. Is there any difference between economic policy uncertainty in crisis period and without crisis? Could have economic policy uncertainty impact on economic growth and innovation? The answer is yes.

The analyses suggest that impact of crises on economic policy is negative. In first period 2001-2007 the impact of economic policy uncertainty on economic growth was negative too but not as strong as in crisis period. The coefficient of determination is in second period (2008-2012) much higher $(66 \%)$ than in the first one $(25 \%)$ and the significance level of model is better in second period too. The crisis period analyses higher quantitative relations. 
In crisis period the government is obligated to take special measure to counter the crises consequences, eventually to prevent its deepening. Approved steps not have to be direct and effective, that is why they should be often changed. And additionally the government is not able to specify time of their validity. All these aspects increase Economic Policy Uncertainty. If economic subjects perceive economic policy uncertain, they could react differently than they were supposed to. They delay their entry decision and reduce firm investment, contracts etc, which could have negative impact on innovation.

\section{REFERENCES}

[1] A. A. Marcus, "Policy uncertainty and technological innovation," Acad. Manage. Rev., vol. 6, no. 3, pp. 443-448, July 1981.

[2] G. Manso, "Motivating innovation," Journal of Finance, vol. 66, issue 5, pp. 1823-1860, October 2011.

[3] M. Friedman, "The role of monetary policy," The American Economic Review, vol. 58, no. 1, pp. 1-17, March 1968.

[4] R. Higgs, "Why the great depression lasted so long and why prosperity resumed after the war," The Independent Review, vol. 4, no. 1, pp. 561-590, Spring 1997.

[5] R. S. Pindyck. (September 1991). Irreverstibility, uncertainty, and investment. Journal of Economic Literature. [Online]. 29(3). pp. 1110-1148. Available: http://www.jstor.org/stable/2727613

[6] D. Rodrik, "Policy uncertainty and private investment in developing countries," Journal of Development Economics, vol. 36, no. 2, pp. 229-242, 1991

[7] S. Baker, N. Bloom, and S. Davis. (2013). Measuring economic policy uncertainty. Working paper No. 83. [Online]. Available: http://www.policyuncertainty.com/papers.html

[8] S. Gilschrist, J. W. Sim, and E. Zkrajsek. (June 2010). Uncertainty, Financial Friction and Investment Dynamics. [Online]. p. 60. Available: http://www.policyuncertainty.com/papers.html

[9] L. Pastor and P. Veronesi, "Uncertainty about government policy and stock prices," The Journal of Finance, vol. 67, no. 4, pp. 1219-1264, August 2012.

[10] B. Bernanke, "Irreversibility, uncertainty and cyclical investment," Quarterly Journal of Economics, vol. 98, pp. 85-106, 1983.

[11] K. Hasset and G. E. Metcalf, "Investment with uncertain tax policy: does random tax policy discourage investment?" Economic Journal, vol. 109, issue 457, pp. 372-393, 1999.
[12] A. Alesina, S. Ozler, N. Roubini, and P. Swagel, "Political instability and economic growth," Journal of Economic Growth, vol. 1, no. 2, pp. 189-211, September 1996.

[13] INSEAD and WIPO. (2012). The global innovation index 2012 [Online]. $\quad$ p. $464 . \quad$ Available: http://www.globalinnovationindex.org/userfiles/file/GII-2012-Report. pdf

[14] WORLDBANK. (2013). KAM: User guide, background. [Online]. Available: http://web.worldbank.org/WBSITE/EXTERNAL/WBI/WBIPROGRA MS/KFDLP/EXTUNIKAM/0,,contentMDK:20584268 menuPK:143 3162 pagePK:64168445 piPK:64168309 theSitePK:1414721,00.ht $\mathrm{ml}$

[15] R. J. Barro. (1996). Determinants of economic growth: A cross-country empirical study. NBER Working Paper, No. 5698. [Online]. p. 118 Available: http://www.nber.org/papers/w5698.pdf?new_window=1

[16] R. A. Sollow. (1956). Contribution to the theory of economic growth Quartely Journals of Economics. [Online]. 70(1). pp. 65-94. Available:

http://faculty.lebow.drexel.edu/LainczC/cal38/Growth/Solow_1956.p df

[17] R. E. Lucas. (February 1988). On the mechanics of economic development. The Journal of Monetary Economics. [Online]. 22(1) pp. 3-42. Available: ttp://www.parisschoolofeconomics.eu/docs/darcillon-thibault/lucasme chanicseconomicgrowth.pdf

[18] P. Romer, "Increasing returns and long-run growth," Journal of Political Economy, vol. 5, pp. 10-19, 1986.

[19] A. Levin, C. F. Li, and C. Chu, "Unit root tests in panel data Asymptotic and finite-sample properties," Journal of Econometrics, no. 108 , pp. $1-24,2002$

[20] J. M. Wooldridge, Introductory Econometric: A Modern Approach, Mason: South-Western Cengage Learning, 2009.

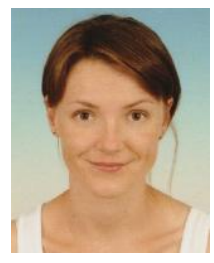

E. Kotlánová was born in Zábřeh in the Czech Republic on February 5, 1979. She studied at the VŠB-Technical University of Ostrava. In 2010 she graduated successfully with a Ph.D. degree there and now she works as an assistant professor at the Silesian University in Opava, School of Business Administration in Karvina, Department of Economics. She is a member of Board of Trustees of Transparency International-Czech Republic

She deals with economics, econonomic policy, corruption, lobbing and national economies. 